\title{
Performance and Gaseous Emissions Characteristics of a Natural Gas/Diesel Dual Fuel Turbocharged and Aftercooled Engine
}

The aim of this paper is to investigate the performance and emissions characteristics of a turbocharged and aftercooled diesel engine operated with natural gas as primary fuel, and diesel fuel as ignition source. In such dual fuel operation, much of the energy released comes from the combustion of the gaseous fuel, while only a small amount of diesel fuel provides ignition through timed cylinder injection. The effects of diesel-natural gas substitution ratios, engine speed, and load on the equivalent brake specific fuel consumption and gaseous emissions of hydrocarbons, carbon monoxide and nitrogen oxides are examined for natural gas-diesel fuel operation and, afterward, compared with the original diesel operation. The results show that, over a wide range of operating conditions (engine speed, load), the dual fuel engine clearly shows the benefits of reduced NOX emissions. However, under low loads, the results indicate high CO and HC emissions and a higher BSFC when compared to those of the corresponding diesel engine.

Keywords: diesel, dual fuel engine, emissions, natural gas

\section{Introduction}

Environmental awareness, stimulated fuel diversification and the high price of conventional fuels have led to the creation of incentives to promote and further evaluate alternative fuel sources for conventional internal combustion engines. One example in compression ignition engines is the use of a gaseous fuel as partial supplement to liquid fuel. Such operation, known as "dual fuel", represents an attractive and flexible means for utilizing a range of gaseous fuels, including natural gas. The dual concept involves the utilization of gaseous fuel by first mixing it with the air intake; ignition of this premixed lean charge is then accomplished by injecting a small quantity of diesel fuel, the "pilot", near top dead centre of the compression stroke. This pilot fuel can readily autoignite to provide an ignition source for subsequent flame propagation within the surrounding gaseous fuel-air mixture (Badr et al., 1999; Kusaka, 2000).

Many investigations regarding combustion phenomena and exhaust emissions in gas-fuelled diesel engines have been conducted. Elliott and Davis (1951), in an early study on a direct injection, naturally aspirated CFR (Cooperative Fuel Research) engine, indicating that the proportion of gas reacted depends on the gas-air mixture strength and on the quantity of diesel employed. They suggested, on this basis, an apparent lower limit of flammability of the mixture. Tesarek (1975) who fumigated natural gas in a single cylinder, direct injection diesel engine and replaced up to $80 \%$ (on an energy basis) of the liquid fuel with natural gas (mainly to reduce particulate emissions) observed very large associated increases in hydrocarbons (HC) and carbon monoxide (CO) emissions. Karim (1980), in a review of the combustion process in dual fuel engines, showed that the pilot ignition delay (the time between the start of injection and ignition) increases considerably with the addition of the gaseous fuel, but then subsequently decreases with the addition of further gas. Varde (1983) investigated the use of propane and natural gas as fuels for diesel engines. Experiments were conducted by injecting different quantities of pilot diesel fuel at a fixed injection timing. The pilot quantity and the overall equivalence ratio were found to influence engine performance, emissions and noise. Karim and Liu (1997)

Paper accepted January, 2009. Technical Editor: Demétrio Bastos Neto developed a multi-zone thermodynamic model that was able to describe the combustion processes of dual fuel engines and predict aspects of their performance. The results of this model demonstrated that any measures that tend to increase the size of the combustion regions of the cylinder charge such as increasing the concentration of gaseous fuel or employing a large quantity of pilot fuel can markedly reduce the concentration of unconverted gaseous fuel and carbon monoxide in the exhaust gases. Papagiannakis and Hountalas (2004) investigated the characteristics of dual fuel operation when liquid diesel is partially replaced with natural gas under ambient intake temperature in a single cylinder direct injection diesel engine. They showed the effects of liquid fuel percentage replacement by natural gas on engine performance and emissions. Nwafor (2000) investigated the possibility of substituting a biofuel for diesel fuel in the pilot injection for combustion of natural gas in a single cylinder diesel engine. The pilot fuels used were rape methyl ester and neat rapeseed oil. The test results indicate that engine performance for these alternative pilot fuels was satisfactory and compared favorably with the baseline test result using diesel fuel.

Most of the above mentioned experimental investigations were performed on single cylinder, direct injection, normally aspirated research engines that certainly provide better flexibility of control and economy of testing. On the other hand, there are few studies on larger engines (such as those of Ding and Hill, 1986; Shenghua et al., 2003; Casado, 2005; and Pereira, 2006) that are available in the open literature. Therefore, the extent to which the findings of the above studies apply to other builds of commercial engines requires more study.

The objective of the present work is to investigate the performance and emissions characteristics of a turbocharged and aftercooled diesel engine operated with natural gas and diesel pilot ignition. With this in mind, experimental tests of the dual fuel operation (over a wide range of engine speeds, loads and substitution ratios of natural gas by diesel fuel) were conducted at the Vehicles Laboratory of Pontifical Catholic University of Rio de Janeiro.

\section{Nomenclature}

bmep = break mean effective pressure

$B S F C=$ brake specific fuel consumption, $g /(k W . h)$

$C F R=$ cooperative fuel research

$C O=$ carbon monoxide 


$$
\begin{array}{ll}
\mathrm{CO}_{2} & =\text { carbon dioxide } \\
\mathrm{HC} & =\text { hydrocarbons } \\
\mathrm{H} / \mathrm{C} & =\text { hydrogen/carbon ratio } \\
\mathrm{H}_{2} \mathrm{O} & =\text { water vapor } \\
\mathrm{LHV} & =\text { lower heating value } \\
\dot{m} & =\text { mass flow rate, } \mathrm{kg} / \mathrm{h} \\
\mathrm{NO}_{X} & =\text { nitrogen oxides } \\
P & =\text { power output }, \mathrm{kW} \\
p p m & =\text { parts per million } \\
\mathrm{SR} & =\text { substitution ratio }
\end{array}
$$

\section{Greek Symbols}

$\phi \quad=$ equivalence ratio, dimensionless

\author{
Subscripts \\ AIR air \\ $D$ diesel fuel \\ $D F \quad$ diesel fuel in dual fuel operation \\ $D / N G$ ratio of diesel fuel to natural gas \\ NG natural gas \\ $O D$ diesel fuel in original diesel operation \\ $T$ total
}

\section{Properties of Natural Gas and Diesel Fuels}

The average composition of natural gas, used in the present experimental investigation, is given in Table 1 (CEG-Rio, 2006). A well-known fact about natural gas (which is more than $90 \%$ methane in composition) is that it exhibits the highest hydrogen/carbon (H/C) ratio of all the fossil fuels. It implies both lower carbon dioxide (CO2) emissions and a lower material intensity (lower mass per unit of energy). If combustion is performed under the best of conditions (correct quantity of oxygen), hydrogen leads to water vapor $(\mathrm{H} 2 \mathrm{O})$, while carbon gives $\mathrm{CO} 2$. Since water emissions have a lower environmental impact than $\mathrm{CO} 2$, a high $\mathrm{H} / \mathrm{C}$ ratio is preferred.
Table 1. Averaged Composition of Natural Gas.

\begin{tabular}{|l|c|}
\hline Component & v/v (\%) \\
\hline Methane $\left(\mathrm{CH}_{4}\right)$ & 90.166 \\
\hline Ethane $\left(\mathrm{C}_{2} \mathrm{H}_{6}\right)$ & 7.462 \\
\hline Propane $\left(\mathrm{C}_{3} \mathrm{H}_{8}\right)$ & 1.277 \\
\hline Butane $\left(\mathrm{C}_{4} \mathrm{H}_{10}\right)$ & 0.028 \\
\hline Pentane $\left(\mathrm{C}_{5} \mathrm{H}_{12}\right)$ & 0.005 \\
\hline Nitrogen $\left(\mathrm{N}_{2}\right)$ & 0.649 \\
\hline Carbon dioxide $\left(\mathrm{CO}_{2}\right)$ & 0.410 \\
\hline Higher molecular weight hydrocarbons $\left(\mathrm{C}_{6}, \mathrm{C}_{7} \& \mathrm{C}_{8}\right)$ & 0.003 \\
\hline
\end{tabular}

Table 2 presents basic information regarding the test fuel properties (CEG-Rio, 2006; Pereira, 2006).

Table 2. Basic Information of Test Fuel Properties (at 1 atm and 20 oC).

\begin{tabular}{|l|c|}
\hline Properties & Value \\
\hline Natural gas & \\
\hline Lower heating value (MJ/kg) & 48.75 \\
\hline Density (kg/m3) & 0.7357 \\
\hline H/C ratio (-) & 3.82 \\
\hline Diesel fuel & \\
\hline Lower heating value (MJ/kg) & 42.45 \\
\hline Cetane number (-) & 45.2 \\
\hline Density (kg/m3) & 830 \\
\hline
\end{tabular}

\section{Experimental Apparatus and Test Conditions}

\section{Experimental Facilities}

The engine used in the present study is an MWM model 4.10 TCA, four cylinder, direct injection, turbocharged, aftercooled diesel. This commercial engine used in a variety of vehicle applications has been properly modified to operate under dual fuel conditions. The technical specifications of the engine are given in Table 3.

Table 3. General Specification of the MWM 4.10 TCA Diesel Engine Test Cases Examined.

\begin{tabular}{|l|c|}
\hline Item & Specification \\
\hline Number of cylinders and arrangement & 4 in-line \\
\hline Bore & $103 \mathrm{~mm}$ \\
\hline Stroke & $129 \mathrm{~mm}$ \\
\hline Displacement & $4.3 \mathrm{~L}$ \\
\hline Compression ratio & $17: 1$ \\
\hline Valves / Cylinders & 2 \\
\hline Speed range & $840-2600 \mathrm{rpm}$ \\
\hline Rated power and Speed & $107 \mathrm{~kW}$ at $2600 \mathrm{rpm}$ \\
\hline Peak torque and Speed & $500 \mathrm{Nm}$ at $1600 \mathrm{rpm}$ \\
\hline Maximum bmep (break mean effective pressure $)$ & $1277 \mathrm{kPa}(12.77$ bar) at $1600 \mathrm{rpm}$ \\
\hline
\end{tabular}

The engine was tested on an AVL model Alpha 240 electric dynamometer, rated for testing engines up to $600 \mathrm{Nm}$ and $8000 \mathrm{rpm}$. The strength of the electromagnetic field coupling the rotating and stationary parts of the dynamometer was adjusted in order to increase or decrease the resistance offered to the engine rotation. Likewise, the diesel engine injection pump was driven by a LENZE linear actuator.

For measurement of the air flow rate, two calibrated nozzles were used. The nozzles were installed in a compensation tank, which was installed upstream of the turbocharger inlet to damp out the air pulsation generated by the engine. The pressure drop across the nozzles was transmitted to the acquisition system using a differential pressure transducer.

The natural gas (obtained from the local distribution network) was introduced through a simple gas-mixer installed just after the air compensation tank. The pressure of the natural gas was 15 psig at the engine intake. Two calibrated nozzles, installed in a tank, and a differential pressure transducer were used to measure the gaseous fuel flow rate. 
A high precision AVL model $733 \mathrm{~S}$ electronic flowmeter was used to measure diesel fuel mass flow rate.

$\mathrm{HC}, \mathrm{CO}$ and $\mathrm{NO}_{\mathrm{X}}$ were measured by sampling the exhaust gases and analyzing them with a TESTO $350 \mathrm{XL}$ emissions analyzer. Before the tests, all the gas sensors of the analyzer were calibrated with standard gases.
The output signals of all the above mentioned instruments, as well as diesel pump throttle, torque, engine speed, temperatures (air, diesel fuel, natural gas, lubricating oil, coolant and exhaust gas), relative humidity (to correct for air consumption) and pressures (air and natural gas) were fed to a Start-AVL data acquisition system. The experimental setup is shown in Fig. 1.

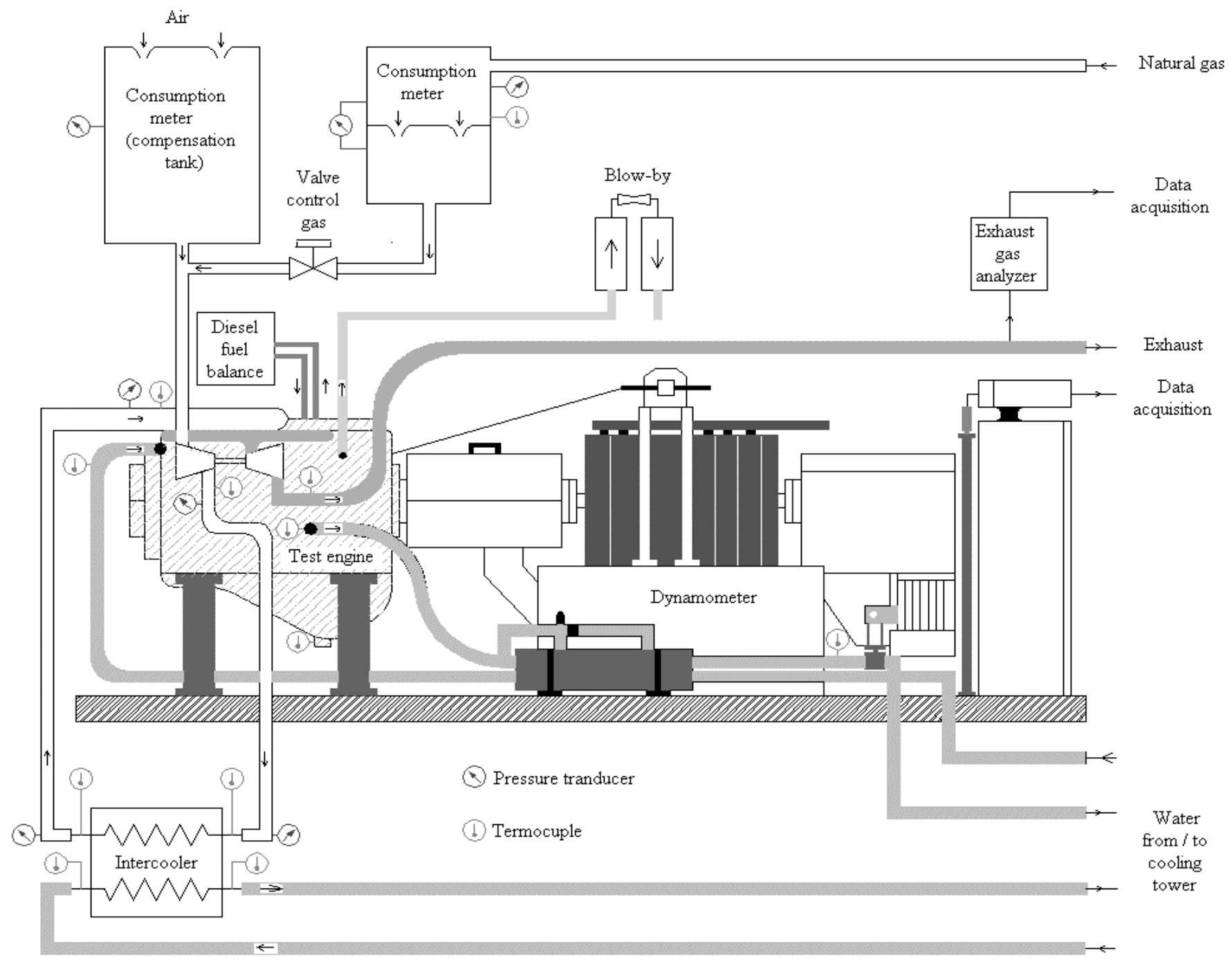

Figure 1. The experimental setup.

\section{Test Conditions Examined}

To determine their effects on the performance and emission characteristics during the dual fuel operation, the speed, load and diesel-fuel/natural-gas substitution ratio were varied. Measurements were taken in the following ranges: load (bmep) from 0 to 12.7 bar, speed from 840 to $2600 \mathrm{rpm}$, substitution ratio from 0 to 94 percent (depending on operating conditions). First of all, the engine was run at a given load and speed under original diesel operation. Then, under the same engine operation conditions (engine speed, load), natural gas was injected with a simultaneous reduction of diesel fuel. Dynamometer control decreased automatically with the diesel fuel mass flow rate in order to maintain constant operating conditions. Thus, the gaseous fuel was increased until reaching an unacceptable operation condition (combustion failure under low loads or presence of audible knock under higher loads). This procedure was employed to assess dual fuel operation with maximum substitution. Additionally, for each examined condition, performance and emissions of the dual fuel combustion were also evaluated using intermediate values for the substitution ratio. In order to calculate the percentage of diesel fuel to natural gas substitution, the Eq. (1) was used:

$$
S R_{D / N G}=\left[1-\left(\frac{\dot{m}_{D F}}{\dot{m}_{O D}}\right)\right]
$$


where $\dot{m}_{D F}$ and $\dot{m}_{O D}$ represent the diesel fuel mass flow rate in dual fuel and original diesel operation, respectively. Original diesel operation is represented by $S R_{D / N G}=0$ and dual fuel operation by $S R_{D / N G}>0$.

The gas-air equivalence ratio $\left(\phi_{N G}\right)$ is defined as the ratio of the stoichiometric mass of air required for gas combustion alone to the difference between the total air mass and the mass required for complete combustion of the pilot diesel fuel, i.e.

$$
\phi_{N G}=\left(\frac{16.9 \dot{m}_{N G}}{\dot{m}_{A I R}-14.9 \dot{m}_{D}}\right)
$$

where $\dot{m}_{N G}, \dot{m}_{A I R}$ and $\dot{m}_{D}$ are the mass flow rates of natural gas, air and diesel, respectively. The numbers 16.9 and 14.9 represent the air mass flow required for the stoichiometric and complete combustion of $1 \mathrm{~kg}$ of natural gas and diesel used, respectively.

The total fuel-air equivalence ratio is defined as the ratio of the mass of the stoichiometric amount of air required both for combustion of gas and the pilot Diesel to the mass of the actual amount of air consumed by the engine, i.e.

$$
\phi_{T}=\left(\frac{16.9 \dot{m}_{N G}+14.9 \dot{m}_{D}}{\dot{m}_{A I R}}\right)
$$

Likewise, under dual fuel operation, the effective brake specific fuel consumption (BSFC) was estimated from the fuel mass flow rates per unit power output. Also, a correction was made in order to take into account the difference between the lower heating values of both fuels.

$$
B S F C=\left[\frac{\dot{m}_{D}+\left(L H V_{N G} / L H V_{D}\right) \dot{m}_{N G}}{1000 \cdot P}\right]
$$

where $L H V_{N G}$ and $L H V_{D}$ are the lower heating values of both fuels and the power output.

\section{Results and Discussion}

For both engine operations, i.e. using original diesel and using dual fuel, three measurements were taken to average the data for each operating condition (load, engine speed). The duration for each measurement was of one minute at a sampling rate of $100 \mathrm{~Hz}$ per channel. The repeatability of all results and the experimental error were evaluated according to Holman (1989). The maximum uncertainty in any quantity was in the 3.2 to $5.5 \%$ range.

Since the trends are observed for a broad range of loads and engine speeds, results are provided for just ten loads and two engine speeds (1600 and $2600 \mathrm{rpm})$.

\section{Effect of Dual Fuel Operation on the Equivalent Brake}

\section{Specific Fuel Consumption}

Figure 2 provides the variation of the equivalent of brake specific fuel consumption as a function of percentage substitution ratio for various loads at 1600 and 2600 rpm engine speeds.

As shown for low loads, BSFC for dual fuel operation is noticeably higher compared to original diesel operation, even though dual fuel performance is poorer at lower loads and when a higher proportion of natural gas is used. Thus, for example, for the 1.3 bar load, corresponding to $10 \%$ of full load at $1600 \mathrm{rpm}$, BSFC increased from $413 \mathrm{~g} / \mathrm{kW}$.h (verified under original diesel operation) to $926 \mathrm{~g} / \mathrm{kW}$.h (under dual fuel operation with a $69 \%$ substitution ratio). This difference represents a BSFC increase of $124 \%$. However, as engine load increased, this tendency diminished due to more complete combustion of the natural gas. At full loads, BSFC under dual fuel operation is comparable to original diesel operation. For example, at $2600 \mathrm{rpm}$ and $10.7 \mathrm{bar}$, BSFC was around of $253 \mathrm{~g} / \mathrm{kWh}$ at full load, a value approximately constant over the entire substitution range (i.e., from 0 to $93 \%$ percent). On the other hand, increasing the engine speed, whether at 1600 or $2600 \mathrm{rpm}$, tends to raise brake specific fuel consumption. This light deterioration in performance is mainly due to the increase of friction power losses, which increase with engine speed. 

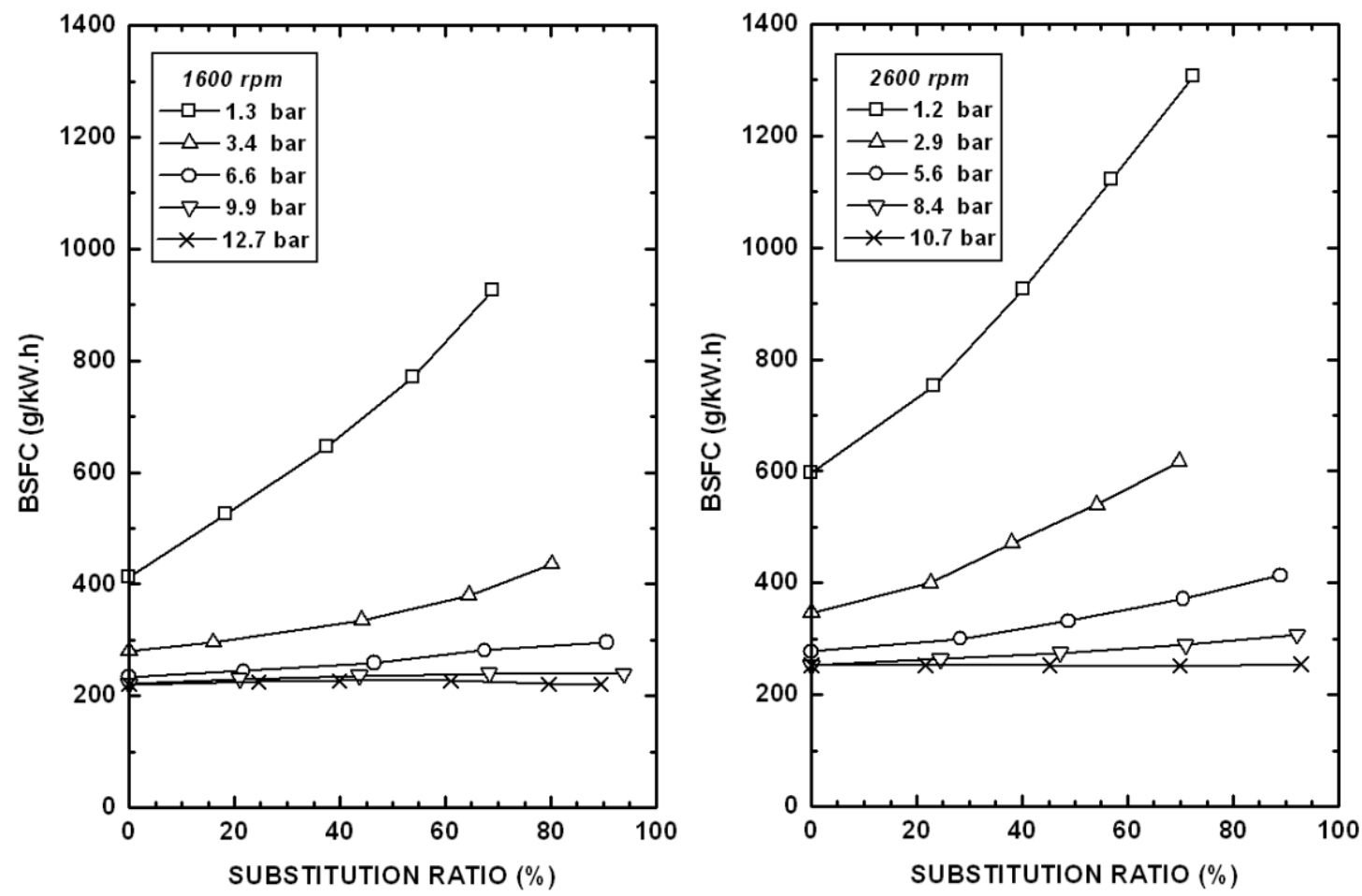

Figure 2. Variation of BSFC for different substitution ratios and engine loads. Engine speeds: 1600 and 2600 rpm.

\section{Effect of Dual Fuel Operation on Hydrocarbon Emissions}

The emissions of hydrocarbons (HC) as a function of substitution ratio are given in Fig. 3 for various engine loads at 1600 and 2600 rpm engine speeds.

Hydrocarbons or, more appropriately, organic emissions are the consequence of incomplete combustion of hydrocarbon fuel (Heywood, 1988). Gaseous hydrocarbon levels in the exhaust of a diesel engine under normal conditions typically range from approximately 20 to 300 ppm (Majewsky and Khair, 2006).

As indicated in Fig. 3, HC emissions under dual fuel operation are considerably higher compared to diesel operation. These results are consistent and explain the BSFC observed in Fig. 2. At low loads, $\mathrm{HC}$ emissions rise rapidly as the substitution ratio of diesel fuel to natural gas is increased. Under these conditions, the natural gas-air mixture is very lean, which complicates flame propagation throughout the whole combustion chamber from the pilot ignition. For the BMEP of 1.3 bar (10\% of full load at $1600 \mathrm{rpm})$ the HC concentration at the exhaust gases was incremented from $160 \mathrm{ppm}$ (original diesel operation) to $20360 \mathrm{ppm}$ (dual fuel operation with $69 \%$ substitution ratio). At this dual fuel operation point, the calculated gas-air ratio was of 0.42 , corresponding to the lower limit of flammability (about $0.4 \sim 0.45$ ) in agreement with the findings of Ding and Hill (1986).

Furthermore, for low load involving very lean gaseous fuel-air mixtures, the employment of a large pilot fuel quantity contributes to combustion of the gaseous fuel without hunting. The reduction of diesel injection mass flow rate, due to the natural gas addition, may change drastically the liquid fuel atomization. The tendency is a poorer atomization when the mass flow rate reduces and this has strong effects on hydrocarbons and carbon monoxide emissions. However, the atomization is most affected when the amount of fuel injected per cycle is reduced below 5 to $10 \%$ of the maximum design level (Abd Alla et al., 2000).

On the other hand, for a constant substitution ratio with an increase in engine load, there is a corresponding decrease in $\mathrm{HC}$ concentrations, indicating an increase in partial reactions or better flame propagation. Under dual fuel operation, lower values of HC concentrations were obtained for loads above 9.9 bar and when the substitution ratio is above approximately 70 percent (corresponding to gas-air ratios above 0.6 ).

Additionally, it is worth noting that when dual fuel engine runs at high speed there is a small increment in $\mathrm{HC}$ emissions. This is believed to be caused by the reduced time available for oxidation reactions. It is important to keep in mind that diesel injection point is fixed and independent of the engine speed. 

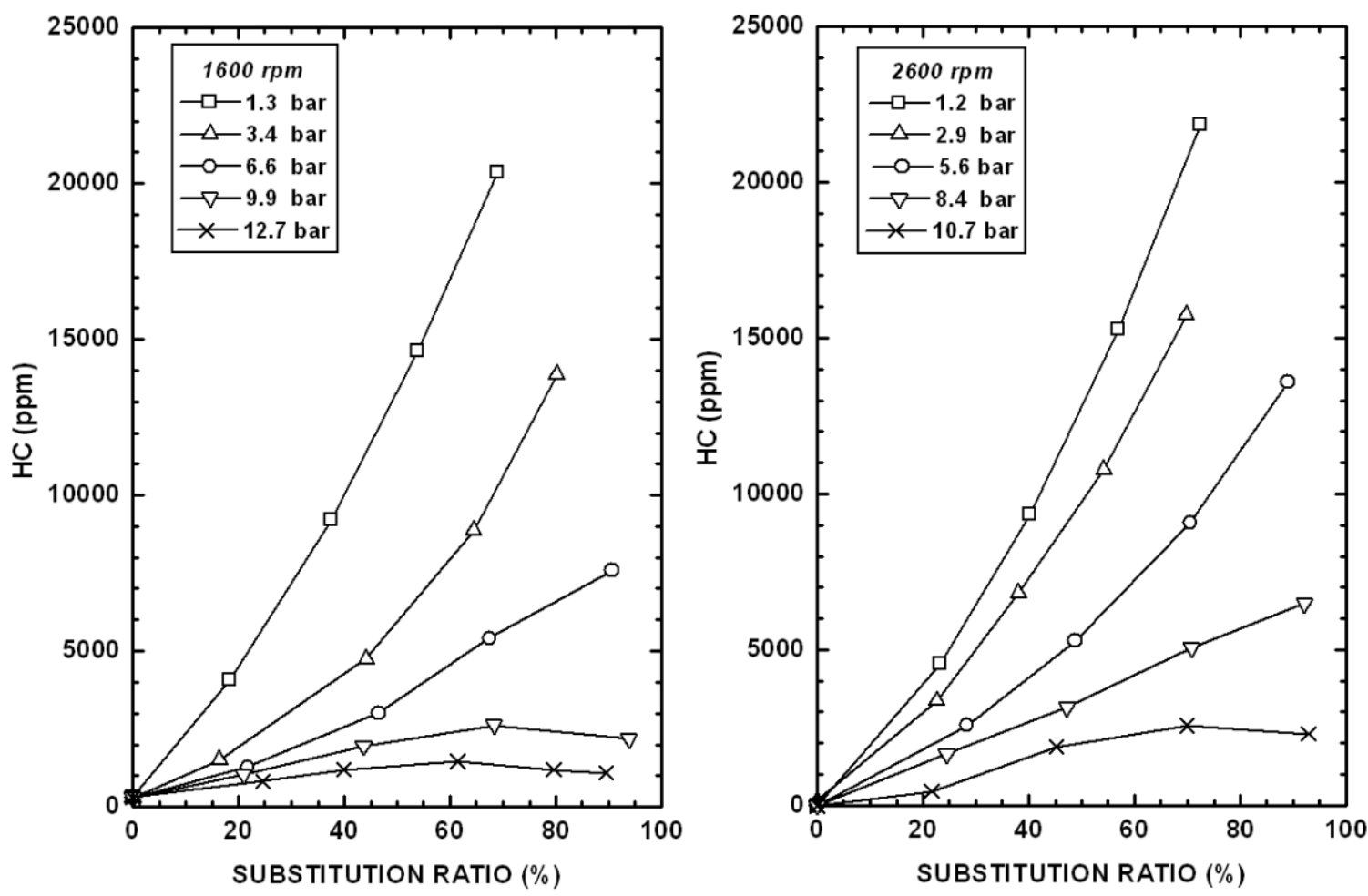

Figure 3. Variation of HC emissions for different substitution ratios and engine loads. Engine speed: 1600 and 2600 rpm.

\section{Effect of Dual Fuel Operation on Carbon Monoxide Emissions}

Figure 4 shows the variation of carbon monoxide emissions as a function of substitution ratio for various loads at 1600 and $2600 \mathrm{rpm}$.

The rate of $\mathrm{CO}$ formation is a function of the available amount of unburned gaseous fuel and of the mixture temperature, both which control the rate of fuel decomposition and oxidation (Kouremenos et al., 1999). Carbon monoxide concentrations in diesel exhaust range from approximately 10 to 500 ppm (Majewsky and Khair, 2006).

Observing Fig. 4, it is confirmed that $\mathrm{CO}$ emissions are consistent with the results for hydrocarbons. Under dual fuel operation, $\mathrm{HC}$ and $\mathrm{CO}$ emissions are considerably higher when compared to diesel operation. For the evaluated loads, increases in substitution ratio correlate with increased $\mathrm{CO}$ emissions. However, each curve peaks (between substitution ratios of 60 and 70 percent) suggest an improvement in oxidation reactions due to the decrease in $\mathrm{CO}$ emissions. Such concentrations were lower under higher loads (above 9.9 bar). Increase in engine speed does not seem to have a significant effect: similar carbon monoxide concentrations are observed for both cases.

Likewise, the $\mathrm{HC}$ and $\mathrm{CO}$ emissions as function of the total fuel-air equivalence ratio (see Fig. 3, Fig. 4 and Table 4) suggest that for $\phi_{T}$ equal to 0.64 or more, the flame propagation can be considered successful, because above this value the $\mathrm{HC}$ and $\mathrm{CO}$ emissions begin to decline. 

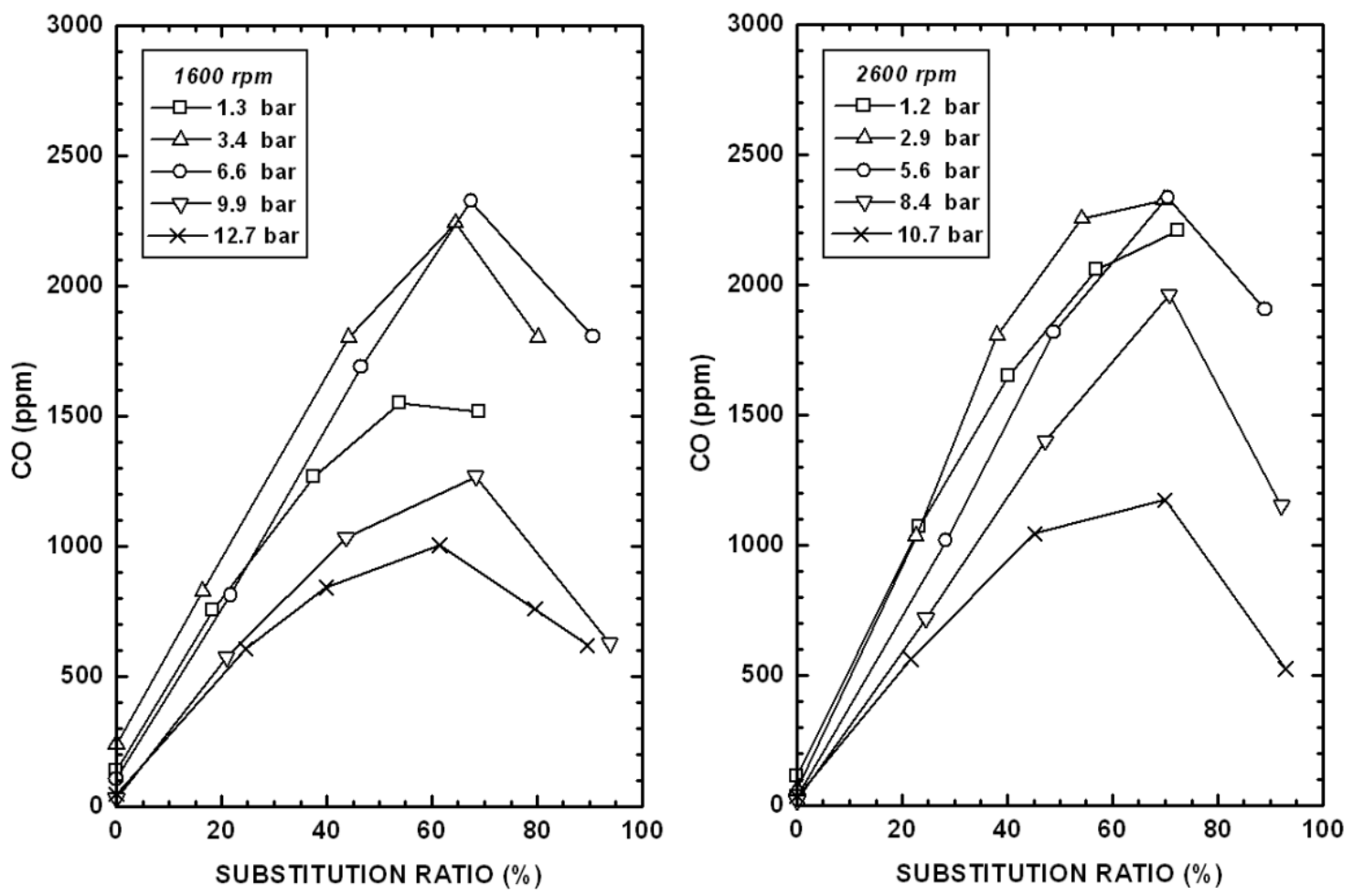

Figure 4. Variation of $\mathrm{CO}$ emissions for different substitution ratios and engine loads. Engine speed: 1600 and $2600 \mathrm{rpm}$.

Table 4. Partial Results of Diesel and Dual Fuel Operations (at 1600 and $2600 \mathrm{rpm})$.

\begin{tabular}{|c|c|c|c|c|c|c|c|}
\hline \multicolumn{4}{|c|}{$1600 \mathrm{rpm}$} & \multicolumn{4}{|c|}{$2600 \mathrm{rpm}$} \\
\hline $\begin{array}{l}\text { Load } \\
\text { (bar) }\end{array}$ & $\begin{array}{c}S R_{D / N G} \\
(\%)\end{array}$ & $\begin{array}{c}\phi_{N G} \\
(-)\end{array}$ & $\begin{array}{l}\phi_{T} \\
(-)\end{array}$ & $\begin{array}{l}\text { Load } \\
\text { (bar) }\end{array}$ & $\begin{array}{c}S R_{D / N G} \\
(\%)\end{array}$ & $\begin{array}{c}\phi_{N G} \\
(-)\end{array}$ & $\begin{array}{l}\phi_{T} \\
(-)\end{array}$ \\
\hline \multirow{5}{*}{1.3} & 0.0 & 0.00 & 0.20 & \multirow{5}{*}{1.2} & 0.0 & 0.00 & 0.22 \\
\hline & 18.3 & 0.10 & 0.25 & & 23.3 & 0.12 & 0.28 \\
\hline & 37.6 & 0.21 & 0.31 & & 40.2 & 0.23 & 0.34 \\
\hline & 53.9 & 0.32 & 0.38 & & 57.0 & 0.35 & 0.42 \\
\hline & 69.0 & 0.41 & 0.45 & & 72.5 & 0.46 & 0.49 \\
\hline \multirow{5}{*}{3.4} & 0.0 & 0.00 & 0.34 & \multirow{5}{*}{2.9} & 0.0 & 0.00 & 0.28 \\
\hline & 16.4 & 0.12 & 0.40 & & 22.6 & 0.12 & 0.33 \\
\hline & 44.1 & 0.30 & 0.45 & & 38.0 & 0.23 & 0.39 \\
\hline & 64.4 & 0.43 & 0.51 & & 54.1 & 0.34 & 0.44 \\
\hline & 80.1 & 0.51 & 0.55 & & 69.7 & 0.45 & 0.50 \\
\hline \multirow{5}{*}{6.6} & 0.0 & 0.00 & 0.47 & \multirow{5}{*}{5.6} & 0.0 & 0.00 & 0.38 \\
\hline & 21.7 & 0.19 & 0.50 & & 28.3 & 0.15 & 0.42 \\
\hline & 46.5 & 0.37 & 0.53 & & 48.8 & 0.29 & 0.46 \\
\hline & 67.4 & 0.49 & 0.57 & & 70.5 & 0.44 & 0.52 \\
\hline & 90.6 & 0.58 & 0.60 & & 89.0 & 0.57 & 0.57 \\
\hline \multirow{5}{*}{9.9} & 0.0 & 0.00 & 0.56 & \multirow{5}{*}{8.4} & 0.0 & 0.00 & 0.48 \\
\hline & 21 & 0.26 & 0.60 & & 24.5 & 0.15 & 0.51 \\
\hline & 43.7 & 0.44 & 0.63 & & 47.2 & 0.30 & 0.53 \\
\hline & 68.3 & 0.57 & 0.66 & & 70.8 & 0.46 & 0.57 \\
\hline & 93.8 & 0.66 & 0.67 & & 92.1 & 0.62 & 0.61 \\
\hline \multirow{6}{*}{12.7} & 0.0 & 0.00 & 0.62 & \multirow{6}{*}{10.7} & 0.0 & 0.00 & 0.61 \\
\hline & 24.6 & 0.36 & 0.67 & & 21.6 & 0.16 & 0.62 \\
\hline & 39.9 & 0.47 & 0.68 & & 45.2 & 0.32 & 0.63 \\
\hline & $\begin{array}{l}61.4 \\
\end{array}$ & 0.59 & 0.70 & & 69.9 & 0.49 & 0.64 \\
\hline & 79.6 & 0.67 & 0.73 & & 92.9 & 0.66 & 0.65 \\
\hline & 89.5 & 0.70 & 0.72 & & - & - & - \\
\hline
\end{tabular}

\section{Effect of Dual Fuel Operation on Nitrogen Oxide Emissions}

The results presented in Fig. 5 show the variation of nitrogen oxide emissions for different substitution ratios and engine loads, at speeds of 1600 and $2600 \mathrm{rpm}$.

Nitrogen oxides, as defined by emissions regulations, include nitric oxide (NO) and nitrogen dioxide $\left(\mathrm{NO}_{2}\right)$. In newer technologies of turbocharged diesel engines, the proportion of $\mathrm{NO}_{2}$ in total $\mathrm{NO}_{\mathrm{X}}$ can be as high as 15 percent or more. $\mathrm{NO}_{\mathrm{X}}$ concentrations in diesel exhaust are typically between 50 and 1000 ppm (Majewsky and Khair, 2006).

As Fig. 5 shows, $\mathrm{NO}_{\mathrm{X}}$ emissions are strongly dependent on the engine load and the presence of natural gas in the charge mixture. Over a wide range of operating conditions (engine speed, load), in comparison with neat diesel fuel, $\mathrm{NO}_{\mathrm{X}}$ emissions were reduced when natural gas and diesel fuels were used in combination. One of the marked features of dual fuel operation is that the ignition delay of the pilot fuel is considerably longer than for the original diesel (Karim, 1980). The increase in the ignition delay would reduce the maximum combustion temperature and, consequently, provide lower $\mathrm{NO}_{\mathrm{X}}$ emissions. Another possible explanation is the low concentration of oxygen in the cylinder charge due to the presence of gaseous fuel, which replaces an equal amount of air.

In contrast to the experimental investigations performed on single cylinder, direct injection, normally aspirated research engines, at higher loads and with the increase of substitution ratio, the $\mathrm{NO}_{\mathrm{X}}$ concentrations showed a tendency to increase. Under such conditions, as more gaseous fuel is burned (as verified in Fig. 3) as more energy is released and the combustion temperature rises, thereby producing more $\mathrm{NO}_{\mathrm{X}}$. The turbocharging increases the mass of air inducted into the engine and allows a proportional increase in the injected fuel quantity, which leads to higher engine output. Furthermore, air velocity through the intake port is higher in 
turbocharged engines relative to naturally aspirated engines. It follows that air motion through the intake port of either a swirlsupported or quiescent combustion system is more likely to enhance mixing and mixture preparation. In general, better mixing leads to higher reaction and oxidation rates and also results in higher combustion temperatures, which in turn causes a reduction in the

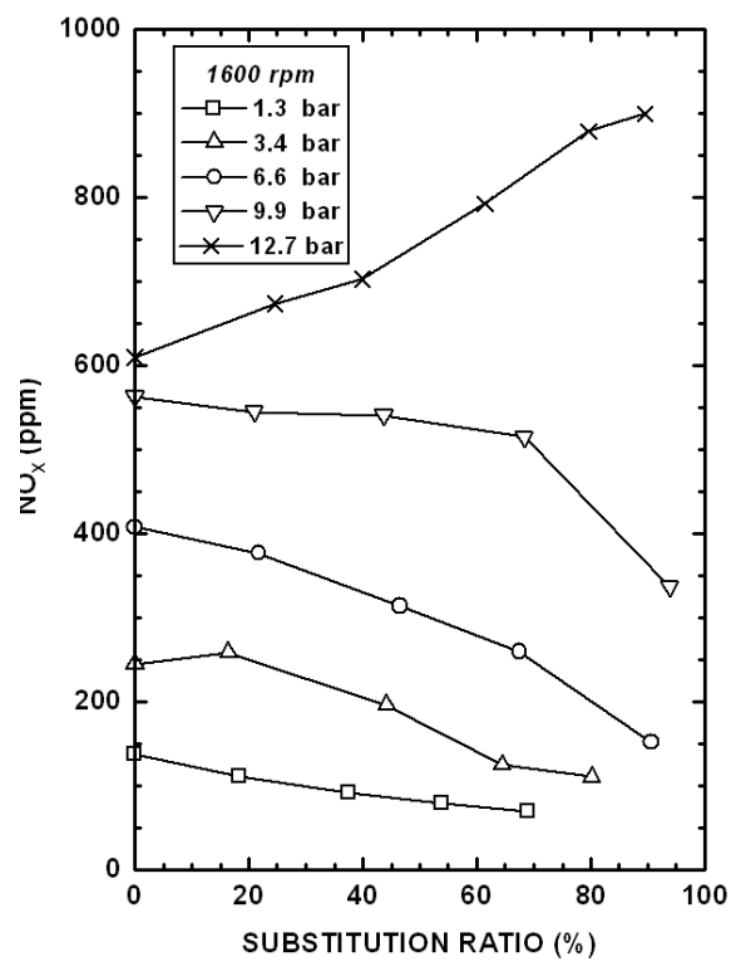

concentration of $\mathrm{HC}$ and $\mathrm{CO}$ emissions and, consequently, an increment of $\mathrm{NO}_{\mathrm{X}}$ emissions (Majewsky and Khair, 2006).

Finally, for both operating modes (original diesel and dual fuel), increases in engine speed result in a slight decline in $\mathrm{NO}_{\mathrm{X}}$ emissions. Thus, the residence time of gases inside the combustion chamber (longer at lower speeds) would be one of the key parameters that determine nitric oxide emissions.

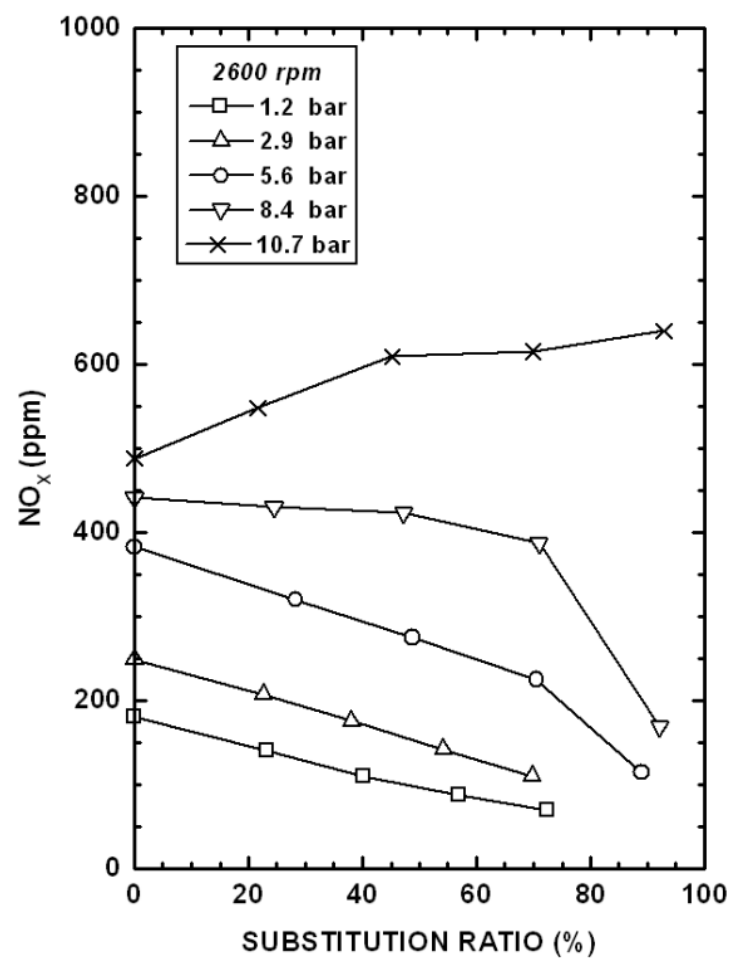

Figure 5. Variation of $\mathrm{NO}_{x}$ emissions for different substitution ratios and engine loads. Engine speed: 1600 and $2600 \mathrm{rpm}$.

\section{Conclusions}

The experimental investigation conducted in this work identified the performance and emissions characteristics of a natural gas/diesel dual fuel turbocharged aftercooled engine; various new phenomena were observed when compared the corresponding original Diesel engine.

At low loads, for the evaluated engine speeds, the equivalent brake specific fuel consumption under dual fuel conditions is significantly higher compared to original diesel operation. Above these loads, dual fuel engine performance is poorer when more natural gas is added. Only at high loads is the combustion of the gaseous fuel more complete and less affected by the substitution ratio, since similar BSFC results are observed for both operating modes. $\mathrm{HC}$ and $\mathrm{CO}$ emissions from the natural gas/diesel engine were significantly higher than those of the original Diesel engine. Theses concentrations increase with substitution ratio and a reduction is observed only under high load conditions and high substitution ratios. Alternatively, over a wide range of the operating conditions (engine speed, load), the dual fuel engine clearly showed the benefits of reduced $\mathrm{NO}_{\mathrm{X}}$ emissions; such reductions must be considered if proposed global reductions are to be achieved with conventional Diesel engines. However, at high loads, as the percentage of substitution increased, higher $\mathrm{NO}_{\mathrm{X}}$ concentrations were recorded.
The results of this study pave the way for future research on optimizing the combustion process of dual fuel commercial engines.

\section{Acknowledgments}

The authors would like to express their gratitude to PETROBRAS S.A., BRASYMPE ENERGIA S.A. and FINEP for their financial support of this study.

\section{References}

Abd Alla, G.H., Soliman, H.A., Badr, O.A. and Abd Rabbo, M.F., 2000, "Effect of pilot fuel quantity on the performance of a dual fuel engine", Energy Conversion and Management, Vol. 41, pp. 559-572.

Badr, O., Karim, G.A. and Liu, B., 1999, "An Examination of the Flame Spread Limits in a Dual Fuel Engine”, Applied Thermal Engineering, Vol. 19, pp. 107-1080.

Casado, M.L., 2005, "Development of a Diesel-Gas Mechanical Dual Fuel Kit" (In Portuguese), M.Sc. Dissertation, Pontifical Catholic University of Rio de Janeiro, RJ, Brazil, 187 p.

CEG-Rio (Companhia Distribuidora de Gás do Rio de Janeiro), 2006, "Natural Gas Composition", Technical Documentation Available for the Vehicles Laboratory of Pontifical Catholic University of Rio de Janeiro.

Ding, X. and Hill, P., 1986, "Emissions and Fuel Economy of a Prechamber Diesel Engine with Natural Gas Dual Fuelling", SAE Paper 86069.

Elliott, M.A. and Davis, R.F., 1951, "Dual Fuel Combustion in Diesel Engine", Ind. and Eng. Chem., Vol. 43, No. 12, pp. 2854-2864. 
Heywood, J.B., 1988, "Internal Combustion Engine Fundamentals”, Ed. McGraw-Hill.

Holman, J.P., 1989, "Experimental Methods for Engineers", Ed. McGraw-Hill.

Karim, G.A., 1980, "A Review of Combustion Processes in the Dual Fuel Engine - The Gas Diesel Engine”, Prog. Energy Combust. Sci, Vol. 6, pp. 277-285.

Varde, K.S., 1983, "Propane Fumigation in a Direct Injection Type Diesel Engine”, SAE Paper 831354.

Kouremenos, D.A., Hountalas, D.T. and Kouremenos, A.D., 1999, "Experimental Investigation of the Effect of Fuel Composition on the Formation of Pollutants in Direct Injection Diesel Engines", SAE Paper 1999-01-0527.

Kusaka, J., Okamoto, T., Daisho, Y., Kihara, R. and Saito, T., 2000, "Combustion and Exhaust Gas Emission Characteristics of a Diesel Engine Dual-Fueled with Natural Gas”, JSAE, Vol. 21, pp. 489-496.

Liu, Z. and Karim, G.A., 1997, "Simulation of Combustion Processes in Gas-Fuelled Diesel Engines", Proc. Instn. Mech. Engrs. - J Power Energy, Vol. 211, pp. 159-169.
Majewsky, W.A. and Khair, M.K., 2006, "Diesel Emissions and Their Control", Ed. SAE International.

Nwafor, O.M.I., 2000, "Effect of Choice of Pilot Fuel on the Performance on Natural Gas in Diesel Engines", Renewable Energy, Vol. 21, pp. 495-504.

Papagiannakis, R.G. and Hountalas, D.T., 2004, "Combustion and Exhaust Emissions Characteristics of a Dual Fuel Compression Ignition Engine Operated with Pilot Diesel Fuel and Natural Gas", Energy Conversion and Management, Vol. 45, pp. 2971-2987.

Pereira, R.H., 2006, "Experimental Investigation and Performance Estimate of Diesel Engines Burning Natural Gas" (In Portuguese), Ph.D. Thesis, Pontifical Catholic University of Rio de Janeiro, RJ, Brazil, 207 p.

Shenghua, L., Longbao, Z., Ziyan, W. and Jiang, R., 2003, "Combustion Characteristics of Compressed Natural Gas/Diesel Dual-Fuel Turbocharged Compressed Ignition Engine", Proc. Instn. Mech. Engrs. - Part D: J. Automobile Engineering, Vol. 217, pp. 833-838.

Tesarek, H., 1975, "Investigations Concerning the Employment Possibilities of Diesel-Gas Process for Reducing Exhaust Emissions, Especially Soot (Particulate Matters)", SAE Paper 750158. 